\title{
PERALIHAN PERAN PASANGAN TERDIDIK ANTARA SUAMI DAN ISTRI
}

\author{
Arif Sugitanata, Moh. Zakariya \\ Program Magister Ilmu Syariah \\ Universitas Islam Negeri Sunan Kalijaga Yogyakarta \\ Email: arifsugitanata@gmail.com, moh.zakariya97@gmail.com
}

\begin{abstract}
Abstrak
Artikel ini membahas bagaimana peralihan peran pasangan terdidik antara suami dan istri dengan menggunakan studi kepustakaan karena bahan dan data dalam penyusunannya menggunakan buku-buku dan jurnal yang berhubungan dengan peralihan peran pasangan terdidik antara suami dan istri, selanjutnya data yang digunakan dalam kajian ini ialah kajian kualititatif, kemudian metode yang digunakan adalah menggunakan deskriptif analitis. Artikel ini menyimpulkan bahwa pasangan suami-istri yang notabene mempunyai latar belakang pendidikan tinggi cenderung kepada pola hubungan modern di mana pembagian peran dalam keluarga bersifat luwes atau tidak kaku, sehingga antara suami-istri tidak merasa terbebani jika melakukan peran publik dan domestik secara bergantian ataupun bersama-sama karena telah kesepakatan sebagai buah dari komunikasi yang berjalan baik dalam keluarga. Namun yang menjadi masalah adalah ketika salah satu atau keduanya tidak mampu membagi peran tersebut dengan baik sehingga memberatkan salah satu pihak. Begitu besar dampak peralihan peran suami-istri dalam sebuah keluarga, khususnya pada keluarga dengan latar belakang suami-istri berpendidikan tinggi, untuk itu dalam membangun relasi keluarga, pembagian tugas, dan pertukaran peran menjadi sangat penting dilakukan dengan sebaik mungkin dengan berprinsip mu'asyaroh bi al-ma'ruf, kesetaran dan keseimbangan dalam keluarga untuk mewujudkan keluarga yang harmonis, keluarga yang sakinah, mawaddah, warohmah.
\end{abstract}

Kata Kunci: Peralihan Peran, Keluarga Terdidik, Suami dan Istri.

\begin{abstract}
This article discusses how the transition of roles of educated couples between husband and wife by using literature study because the materials and data in their preparation use books and journals related to the transition of roles of educated couples between husband and wife, then the data used in this study is a qualitative study, then the method used is descriptive analytical. This article concludes that married couples who in fact have a higher educational background tend to modern relationship patterns where the division of roles in the family is flexible or not rigid, so that husband and wife do not feel burdened if they perform public and domestic roles alternately or together. -the same because there has been an agreement as a result of good communication in the family. However, the problem is when one or both of them are not able to divide these roles properly, thus burdening one of the parties. So big is the impact of changing the roles of husband and wife in a family, especially in families with highly educated husband-wife backgrounds, for that in building family relationships, division of tasks, and role exchanges it is very important to do it as well as possible with the principle of mu'asyaroh bi. al-ma'ruf, equality and balance in the family to create a harmonious family, a sakinah family, mawaddah, warohmah.
\end{abstract}

Keywords: Switching Roles, Educated Family, Husband and Wife 


\section{A. Pendahuluan}

Keluarga ialah bagian penting bagi sebuah tatanan masyarakat, tetapi keluarga mempunyai peran yang tidak kecil dalam mewujudkan masyarakat yang baik. Berfungsinya keluarga dengan baik merupakan syarat mutlak untuk mewujudkan masyarakat yang baik, karena di keluargalah individu baru tercita dan berinteraksi untuk pertama kalinya, di dalamnya juga diajarkan serta ditanamkan nilai dan norma-norma yang sesuai dengan masyarakat. Levy sebagaimana dikutip Herien Puspitawati ${ }^{1}$ menyatakan bahwa syarat-syarat yang harus ada dalam menghadirkan suatu fungsi dari keluarga ialah, pertama, berbagi tugas dan peran serta agenda kegiatan pada ranag keluarga, kedua, menanamkan rasa saling percaya pada ranah hubungan anggota keluarga, ketiga, pengelolaan pengluaran dan pemasukan ekonomi dalam hal barang dan jasa bagi anggota keluarga guna tercapainya tujuan keluarga, keempat, ditribusi kekuasaan dalam keluarga sebagai alokasi politik, dan kelima, setiap anggota keluarga dalam memenuhi tuntutan normanorma yang berlaku diharuskan bisa menintergrasikan dan mengalokasikan cara dan teknik sosialisasi, internalisasi, maupun pelestarian nilai-nilai maupun perilaku pada

Tujuan dari perkawinan adalah untuk memenuhi petunjuk agama dalam rangka membentuk keluarga yang harmonis, sejahtera dan bahagia. Harmonis dalam menggunakan hak dan kewajiban anggota keluarga; sejahtera artinya terciptanya ketenangan lahir dan batin disebabkan terpenuhinya keperluan hidup lahir dan batinnya, sehingga timbulah kebahagiaan, yakni kasih sayang antar anggota keluarga. $^{2}$

${ }^{1}$ Herien Puspitawati, "Konsep dan Teori Keluarga”, (Departemen Ilmu Keguruan Dan Konsumen Fakultas Ekologi Manusia-IPB, 2013), hlm. 7.

${ }^{2}$ Abdul Rahman Ghozali, Fiqh Munakahat (Jakarta : Kencana, 2003), hlm. 22.
Apabila akad nikah telah berlangsung dan sah memenuhi syarat dan rukunya, maka akan menimbulkan akibat hukum. Dengan demikian, akan memunculkan hak dan kewajiban selaku suami istri dalam keluarga. ${ }^{3}$ Mengenai hak dan kewajiban suami istri diantaranya tercantum dalam perundang-undangan salah satunya dalam Kompilasi Hukum Islam pada Pasal 80 mengenai kewajiban suami dan pada pasal 83 mengenai kewajiban istri. Pada Pasal 80 diantaranya dijelaskan yaitu suami memiliki kewajiban membimbing istri dan rumah tangganya, melindungi istrinya dan memberikan pendidikan, serta sesuai dengan kemampuannya suami berkewajiban untuk menanggung nafkah, kiswah dan tempat kediaman istri, biaya rumah tangga dan perawatannya, biaya pendidikan bagi anak dan lain-lain. Sedangkan istri berkewajiban untuk berbakti lahir dan batin kepada suami di dalam batas-batas yang dibenarkan oleh hukum Islam, menyelenggarakan dan mengatur keperluan rumah tangga dengan sebaikbaiknya.

Berdasarkan penjelasan dalam pasal tersebut dapat kita ketahui bahwa kewajiban nafkah ada di tangan suami. Kemudian kewajiban istri salah satunya taat kepada suami, hanya dalam hal-hal yang dibenarkan agama, bukan dalam hal kemaksiatan kepada Allah SWT. Hal ini dijelaskan pula dalam Alquran, diantaranya dalam Q.S. an-Nisa (4) : $34:^{4}$

Maksud dari "nafkah" dalam Q.S. an-Nisa (4) : 34 adalah penyediaan kebutuhan istri, seperti makanan, tempat tinggal, pembantu, dan obat-obatan, meskipun dia kaya. Pemenuhan "nafkah" merupakan sesuatu yang wajib. ${ }^{5}$ Maka

Munakahat. 155.
${ }^{4}$ Tim Penterjemah Alquran Kemenag RI, Alquran dan Terjemahnya (Surakarta: Pustaka Al Hanan, 2009), hlm. 84.

5 Sayyid Sabiq, Fiqh Sunnah, II (Jakarta: Darul Haq, tt), hlm. 485. 
semua kebutuhan tersebut menjadi kebutuhan yang harus terpenuhi.

Jika kita lihat Kompilasi Hukum

Islam dan ayat Alquran di atas, maka kewajiban nafkah berada di tangan ayah atau suami sebagaimana Allah SWT telah melebihkan mereka dari sebagian yang lain. Suami bertugas memenuhi kebutuhan yang berkaitan dengan nafkah atau pemenuhan kebutuhan ekonomi diberatkan kepadanya, sedangkan tugas istri bertugas mengatur rumah tangga. Hal tersebut dikarenakan pada dasarnya, pernikahan mempunyai konsekuensi moral, sosial dan ekonomi yang kemudian melahirkan sebuah peran dan tanggung jawab sebagai suami atau istri.

Peran menurut Soerjono Soekanto merupakan aspek dinamis yang berkaitan dengan kedudukan (status) seseorang, apabila seseorang melaksanakan hak dan kewajibannya sesuai dengan kedudukannya, maka ia menjalankan suatu peranan. ${ }^{6}$ Setiap orang memiliki peranannya masing-masing, baik dalam kehidupan bermasyarakat maupun kehidupan berumah tangga. Dalam sebuah keluarga, setiap anggota keluarga mempunyai fungsi atau peranya masingmasing. Perbedaan peran dalam keluarga sangat dipengaruhi oleh sosial-ekonomi dan budaya masyarakat. Masyarakat dengan budaya patriarkhi menentukan bahwa tanggung jawab mencari dan menyediakan nafkah keluarga adalah ayah (suami). ${ }^{7}$ Sedangkan ibu (istri) lebih fokus pada peran reproduksi dalam ranah domestik. Pembakuan peran suami dan istri secara dikotomis publik-produktif diperankan oleh suami, sementara peran domestik-reproduktif merupakan peran istri sudah mengakar kuat di masyarakat. ${ }^{8}$

${ }^{6}$ Soerjono Soekanto, Budi Sulistiyowati, Sosiologi Suatu Pengantar (Jakarta : Rajawali Press, 2017), hlm. 210-211.

${ }^{7}$ Mufidah Ch, Psikologi Keluarga Islam Berwawasan Gender (Edisi Revisi), (Malang: UINMaliki Press, 2014), hlm 127.

${ }^{8}$ Mufidah Ch, Psikologi Keluarga Islam Berwawasan Gender, 127
Semakin pesat dan majunya pendidikan maka peran perempuan yang sebelumnya hanya sebagai ibu rumah tangga yakni melayani suami, bekerja hanya pada ranah domestik, Namun pada saat ini, perempuan juga turut dan mampu mengisi ranah-ranah publik dalam suatu pekerjaan bahkan suatu jabatan dipemerintahan yang menimbulkan suatu perkembangan pada tatanan nilai maupun keluarga. ${ }^{9}$ Keadaan yang demikian menjadi suatu cikal bakal perempuan sebagai pencari nafkah.

Era sekarang sudah terbuka luas dan sama dengan laki-laki bagi perempuan dalam mencari suatu pekerjaan atau berkarir, tidak jarang perempuan menduduki posisi yang setara dan bahkan lebih dari laki-laki serta kuantitas dari perempuan yang semakin meningkat. Kehadiran perempuan sebagai pencari nafkah dalam hal ini seorang istri bagi keluarga memberikan suatu peran tambahan yang harus dijalani yakni sebagai ibu dan sebagai pencari nafkah, artinya di sini istri bisa mengemban dua peran ganda dan bisa dikatakan lebih berta dari suami. $^{10}$

Pada dasarnya kunci utama dalam membangun relasi suami dan istri dalam sebuah keluarga adalah relasi yang berdasarkan prinsip mu'asyaroh bi alma'ruf (pergaulan suami istri yang baik). Prinsip mu'asyaroh bi al-ma'ruf telah dipertegas dalam firman Allah SWT dalam Surah an-Nisa ayat 19 yang memberikan pengertian bahwa dalam sebuah perkawinan harus dibangun relasi yang baik antar anggota keluarga khususnya suami dan istri yang bersumber pada pola interaksi positif, harmonis dengan suasana

9 Iftidah, "Pengaruh Pemahaman Keagamaan Masyarakat Desa Dempet Terhadap Pola Relasi Suami Isteri Bekerja”, Jurnal HARMONI: Multikultural dan Multireligius Vol. 17, No. 2 (Juli-Desember 2018), hlm, 520.

10 Iftidah, "Pengaruh Pemahaman Keagamaan Masyarakat Desa Dempet Terhadap Pola Relasi Suami Isteri Bekerja”, Jurnal HARMONI: Multikultural dan Multireligius Vol. 17, No. 2 (Juli-Desember 2018), hlm, 520. 
hati yang dipenuhi kedamaian, yang tercermin dari terwujudnya keseimbangan pemenuhan hak dan kewajiban. ${ }^{11}$ Keharmonisan keluarga akan terwujud apabila masing-masing unsur dalam keluarga mampu berfungsi dan berperan sebagaimana mestinya. ${ }^{12}$

Dewasa ini banyak kejadian di masyarakat yang memperlihatkan keadaan keluarga yang tidak harmonis yang kebanyakan dari ketidakharmonisan tersebut berakhir dengan perceraian. Para pelaku keluarga yakni suami-istri tidak melaksanakan hak dan kewajiban sehingga kehilangan peran yang menjadikan keluarga kehilangan kedamaian dan kasih sayang.

Melihat pada hukum dasarnya, syariat Islam meletakan beban nafkah untuk dapat dipenuhi di tangan suami, namun tidak tertutup kemungkinan bahwa peran tersebut dilakukan oleh istri atas dasar suka rela dan karena kebutuhan. Industri, teknologi, dan pendidikan yang semakin berkembang mempengaruhi pola pikir masyarakat, tidak terkecuali perempuan. Seorang istri yang bekerja tentu akan membuatnya memiliki penghasilan sendiri yang dapat membantu suami dalam urusan nafkah dan pemenuhan kebutuhan keluarga, namun yang menjadi perhatian adalah bagaimana peran utamanya dalam ranah domestik, mengurus ruamh tangga, melayani suami, dan mengurus anak-anak, apakah ia dapat menyeimbangkan peran domestik dan publik yang ia miliki sekaligus itu. Kemudian bagaimana pula peran suami

${ }^{11}$ Mufidah Ch, Psikologi Keluarga Islam Berwawasan Gender, hlm 161.

${ }_{12}$ Maria Agustin dan Fabiola Hendrati, "Hubungan Kemandirian Istri dengan Keharmonisan Perkawinan pada Tahap Awal Perkawinan di Kelurahan Pagentan Kecamatan Singosari Kabupaten Malang", Jurnal Psikologi Tabularasa, Volume, No. 2 (Agustus 2013), hlm. 692.

13 Ismiyati, "Tinjauan Yuridis Tentang Relasi Suami-Isteri Menurut KHI Inpres No. 1/1991", Jurnal MMH Fakultas Hukum Universitas Diponegoro Semarang, Jilid 42, No. 3 (Juli 2013), hlm. 369. dalam keluarga yang demikian, apakah ia tetap berperan pada ranah publik saja, atau selain berperan publik suami ikut serta membantu istri pada ranah domestik, atau malah suami menggantikan peran istri pada ranah domestik. Akibat peralihan ini tentu akan berdampak pula pada keluarga, apakah peralihan peran seperti demikian akan memberi berdampak baik, atau malah berdampak buruk terhadap keluarga termasuk anak.

Berkaitan dengan tema peralihan peran suami dan istri, ada beberapa penelitian yang dilakukan, baik dalam bentuk skripsi, tesis, ataupun jurnal. Beberapa penelitian terdahulu tersebut antara lain tesis yang ditulis oleh Nurhikmah Hairak H. Biga ${ }^{14}$ yang berjudul "pembagian peran dalam keluarga dan pengaruhnya terhadap perceraian pasangan muslim berpendidikan tinggi”. Tesis Nurhikmah Hairak H. Biga membahas masalah-masalah yang dihadapi sehingga melakukan perceraian dan pembagian peran pada keluarga pasangan berpendidikan tinggi. Elvida Sapitri ${ }^{15}$ yang berjudul "pembagian peran antara suami istri dan implikasinya terhadap keharmonisan keluarga (studi kasus di gampong lawe cimanok kecamatan kluet timur kabupaten aceh selatan)". Skripsi Elvida Sapitri mencoba menjelaskan bagaimana pembagian peran suami istri dan dampak yang ditimbulkan dari ketidak berfungsian peran suami maupun istri.

Berikutnya jurnal yang ditulis oleh Achmad Irwan Hamzani ${ }^{16}$ yang berjudul

\footnotetext{
${ }^{14}$ Nurhikmah Hairak H. Biga, "Pembagian Peran dalam Keluarga dan Pengaruhnya Terhadap Perceraian Pasangan Muslim Berpendidikan Tinggi" Tesis, Fakultas Syari'ah dan Hukum Universitas Islam Negeri Sunan Kalijaga Yogyakarta (2015)

15 Elvida Sapitri, "Pembagian Peran Antara Suami Isteri Dan Implikasinya Terhadap Keharmonisan Keluarga (Studi Kasus di Gampong Lawe Cimanok Kecamatan Kluet Timur Kabupaten Aceh Selatan)" Skripsi, Fakultas Dakwah dan Komunikasi Jurusan Pengembangan Masyarakat Islam Universitas Islam Negeri Ar-Raniry (2017).

16 Achmad Irwan Hamzani, "Pembagian Peran Suami Isteri dalam Keluarga Islam Indonesia
} 
"pembagian peran suami istri dalam keluarga Islam Indonesia (analisis gender terhadap inpres No. 1 tahun 1991 tentang Kompilasi Hukum Islam)". Jurnal ini berusaha untuk mengidentifikasi bias gender terhadap pembagian peran suami istri dalam Kompilasi Hukum Islam.

Dalam tulisan ini, penyusun hendak menjelaskan bagaimana peralihan peran suami dan istri pada pasangan terdidik dan dampaknya terhadap keluarga. Kajian ini menggunakan studi kepustakaan karena bahan dan data dalam penyusunannya menggunakan buku-buku dan jurnal yang berhubungan dengan peralihan peran pasangan terdidik antara suami dan istri, selanjutnya data yang digunakan dalam kajian ini ialah kajian kualititatif, kemudian metode yang digunakan adalah menggunakan deskriptif analitis

\section{B. Pembahasan.}

\section{Peran Suami dan Istri dalam Keluarga}

Masyarakat dengan budaya

patriarkhi menentukan bahwa tanggung jawab mencari dan menyediakan nafkah keluarga adalah ayah (suami). ${ }^{17}$ Sedangkan ibu lebih fokus pada peran reproduksi dalam ranah domestik. Pembakuan peran suami dan istri secara dikotomis publikproduktif diperankan oleh suami, sementara peran domestik-reproduktif merupakan peran istri sudah mengakar kuat di masyarakat. ${ }^{18}$ Pebakuan peran tersebut sebenarnya tidak menjadi sebuah masalah jika istri yang menghendaki demikian, memilih menjadi ibu rumah tangga tanpa tekanan dan paksaan siapapun, dan di dasari oleh argumentasi dan pertimbangan yang justru memberikan kenyamanan bagi istri.

Pembagian peran ini sesungguhnya tidak menjadi masalah jika kedua wilayah

(Analisis Gender terhadap Inpres No. 1 tahun 1991 tentang Kompilasi Hukum Islam)", Jurnal SOSEKHUM (e-Journal.uptegal.ac.id), 2010.

${ }^{17}$ Mufidah Ch, Psikologi Keluarga Islam Berwawasan Gender (Edisi Revisi), (Malang: UINMaliki Press, 2014), hlm 127.

${ }^{18}$ Ibid peran tersebut mendapat penghargaan yang setara. Namun kenyataanya, di masyarakat justru telah terbentuk image bahwa peran publik-produktif lebih tinggi karena mendapatkan penghasilan (dibayar). Sedangkan peran domestik-reproduktif rumah tangga lebih rendah karena tidak menghasilkan uang. Pembagian tersebut kemudian berlanjut pada laki-laki (suami) lebih tinggi derajatnya dari perempuan (istri) karena dialah yang menjadi tulang punggung keluarga, pencari nafkah dan pengendali hak-hak keluarga yang ditanggungnya. ${ }^{19}$

Sesuai dengan keterangan dalam Alquran Surah an-Nisa (4) ayat 34, bahwa laki-laki (suami) merupakan pemimpin bagi perempuan (istri) yang disebabkan karena kelebihan atau keutamaan suami atas istri. Perlu dicermati lebih lanjut tentang ayat ini, pertama: Ayat ini menggunakan kata "rijal" dan "nisa" bukan menggunakan kata "dzakarun" dan "untsa". Yang dimaksud kepemipinan, kelebihan derajat yang lebih tinggi bukan semata-mata berangkat dari kodrat, karena kata "rijal" lebih dekat pemaknaanya dengan peran dan tanggung jawab sosial yang bisa berubah tergantung pada kondisi dan situasinya. Kedua: Kepemipinan dan kelebihan dalam konteks rumah tangga ini berkaitan dengan peran pencari nafkah yang pada umumnyalebih siap diperankan oleh laki-laki (suami) dari pada perempuan akibat adanya pembakuan peran. ${ }^{20}$ Peran pencari nafkah sesungguhnya bukan berdasarkan pada kodrat, tetapi terkait dengan tanggung jawab sosial yang dapat dilakukan oleh siapa saja yang siap dan mampu menjalankan peran tersebut.

Dewasa ini banyak kejadian di masyarakat yang memperlihatkan keadaan keluarga yang tidak harmonis yang kebanyakan dari ketidakharmonisan tersebut berakhir dengan perceraian. Para pelaku keluarga yakni suami-istri tidak melaksanakan hak dan kewajiban sehingga kehilangan peran yang menjadikan

\footnotetext{
${ }^{19}$ Ibid, hlm. 128-129.

${ }^{20}$ Ibid, hlm. 130-131.
} 
keluarga kehilangan kedamaian dan kasih sayang. ${ }^{21}$ Peran suami dan istri dalam keluarga adalah berkaitan dengan hak dan kewajiban dalam keluarga. Oleh karena itu, pembahasan tentang hak dan kewajiban suam-istri sangatlah diperlukan agar suami-istri dapat mencapai tujuan perkawinan dan terhindar dari perceraian. Hak adalah segala sesuatu yang harus diterima seseorang setelah melaksanakan kewajiban, sedangkan kewajiban adalah segala sesuatu yang harus dikerjakan untuk orang lain sebelum menerima hak. ${ }^{22}$

Pada dasarnya kunci utama dalam membangun relasi suami dan istri dalam sebuah keluarga adalah relasi yang berdasarkan prinsip mu'asyaroh bi alma'ruf (pergaulan suami istri yang baik). Prinsip mu'asyaroh bi al-ma'ruf telah dipertegas dalam firman Allah SWT dala Surah an-Nisa (4) ayat 19 yang memberikan pengertian bahwa dalam sebuah perkawinan harus dibangun relasi yang baik antar anggota keluarga khususnya suami dan istri yang bersumber pada pola interaksi positif, harmonis dengan suasana hati yang dipenuhi kedamaian, yang tercermin dari terwujudnya keseimbangan pemenuhan hak dan kewajiban. ${ }^{23}$ Berkaitan dengan hak dan kewajiban suami dan istri sebagaimana dijelaskan dalam Alquran Surah alBaqarah (2) ayat 228:

$$
\text { ولهنّ منثل الّّي عليهنّ بالمعروف. }
$$

Dan para wanita mempunyai hak seimbang dengan kewajibannya menurut cara yang baik (ma'ruf).

21 Ismiyati, "Tinjauan Yuridis Tentang Relasi Suami-Isteri Menurut KHI Inpres No. 1/1991", Jurnal MMH Fakultas Hukum Universitas Diponegoro Semarang, Jilid 42, No. 3 (Juli 2013), hlm. 369.

${ }^{22}$ Amir Syarifuddin, Hukum Perkawinan Islam di Indonesia (Analisis Fiqh Munakahat dan Undang-Undang Perkawinan), (Jakarta: Kencana, 2006), hlm. 159.

${ }^{23}$ Mufidah Ch, Psikologi Keluarga Islam Berwawasan Gender, hlm 161.
Dalam hadis yang diriwayatkan Amru bin Ash Nabi Muhammad SAW bersabda yang artinya:

"Ketahuilah bahwa kamu
mempunyai hak yang harus dipikul
oleh istrimu, dan istrimu juga
mempunyai hak yang harus kamu
pikul"

Dari penjelasan Alquran dan Hadis di atas dijelaskan bahwa suami dan istri mempunyai hak dan kewajiban dalam kehidupan rumah tangga, dimana kedudukan hak dan kewajiban tersebut adalah seimbang atau setara dan mempunyai hubungan timbal balik antara keduanya. Di penghujung ayat itu dijelaskan bahwa kedudukan suami setingkat lebih tinggi dibanding istrinya, karena suami bertanggung jawab terhadap keselamatan dan kesejahteraan keluarganya, dengan memberi nafkah dan membimbing serta melindungi istrinya. Adapun keterangan tentang hak dan kewajiban menurut yuridis atau perundang-undangan dapat dilihat pada Undang-undang Perkawinan Bab IV Pasal 30 sampai 34 serta pada Kompilasi Hukum Islam Bab XII Pasal 77 sampai 84.

\section{Landasan Kebolehan Istri Bekerja di Ranah Publik}

Pada dasarnya, Islam tidak melarang istri untuk bekerja, bahkan bekerjanya seorang istri dapat menjadi wajib atau sunnah, tergantung pada kondisi yang ada. ${ }^{24}$ Apabila kondisinya memang mengharuskan untuk bekerja, seperti tidak adanya seorang wanita yang ahli dalam bidang kesehatan yang berhubungan dengan reproduksi wanita, maka bekerja baginya menjadi suatu kewajiban. Hal itu diperbolehkan selama ia dapat menjaga adab-adab pergaulan agar terpelihara kehormatan dan wibawanya, serta tidak mengabaikan kewajibanya untuk

\section{Iftidah, "Pengaruh Pemahaman} Keagamaan Masyarakat Desa Dempet Terhadap Pola Relasi Suami Isteri Bekerja”, hlm, 522. 
memelihara rumah tangga dan mendidik anak. $^{25}$

Berkaitan dengan prinsip keadilan dan persamaan sebagaimana penulis kutip dari buku yang ditulis Khoiruddin Nasution, ${ }^{26}$ bahwa hak wanita sesuai dengan kewajibanya, sebagaimana disebutkan dalam Surah al-Baqqarah (2) ayat 228 dan ganjaran amal perbuatan lakilaki dan perempuan yang termaktub dalam Surah an-Nahl (16) ayat 97:

Banyak ayat-ayat lain yang mendiskripsikan mengenai kesamaan suatu prinsip tanpa terkecuali mengenai keadilan. Artinya, kebebasan bekerja pada ranah publik terbuka luas kepada semua manusia baik laki-laki atau perempuan dengan tidak membedakan jenis kelamin, sebagai catatan telah memenuhi ketentuanketentuan yang ditetapkan dan yang tidak kalah pentingnya ialah pekerjaan tersebut halal. ${ }^{27}$ Bekerja juga merupakan hak seorang wanita. Bekerja adalah hak asasi manusia, tidak ada bedanya untuk anakanak ataupun orang dewasa, lelaki dan perempuan, terpelajar atau orang awam, kaya atau miskin, siapa pun tidak dilarang bekerja, kecuali jika membahayakan diri dan/atau orang lain. ${ }^{28}$ Islam melalui melalui banyak sekali ayat-ayat Alquran mendorong untuku bekerja, sebagaimana firman Allah SWT dalam Surah. alJumu'ah (62) ayat 10: "Apabila telah ditunaikan salat, maka bertebaranlah kamu di muka bumi, dan carilah karunia Allah, dan ingatlah Allah banyak-banyak supaya kamu beruntung”. Kemudian dalam Surah. al-Hud (11) ayat: 61: “..dan menjadikan kamu pemakmurnya.."

Bekerja secara umum merupakan kewajiban syar'i, karena hanya dengan bekerjalah nafkah wajib dapat dipenuhi,

${ }^{25}$ Ibid

${ }^{26}$ Khoiruddin Nasution, Hukum Perdata (Keluarga) Islam Indonesia dan Perbandingan Hukum Perkawinan di Dunia Muslim, (yogyakarta: ACAdeMIA + TAZZAFA, 2009), hlm. 252-253.

${ }^{27}$ Ibid., hlm. 253.

${ }^{28}$ Hannan Abdul Aziz, Saat Isteri Punya Penghasilan Sendiri, (Solo: PT. Aqwam Media Profetika, 2012), hlm. 85. seperti nafkah untuk diri sendiri, istri, anak, ataupun untuk kedua orang tua. Dengan demikian, bekerja adalah adalah hak setiap orang tanpa membedakan latar balakang agama, jenis kelamin, suku, ataupun warna kulit.

\section{Peralihan Peran Pasangan Terdidik Antara Suami dan Istri}

Sebagaimana telah dibahas di atas bahwa dalam sebuah keluarga, setiap anggota keluarga mempunyai fungsi atau peranya masing-masing. Seiring dengan perkembangan zaman, budaya patriarkhi yang menempatkan istri hanya pada ranah domestik saja perlahan mulai luntur dengan semakin meningkatnya pengetahuan dan pemahaman masyarakat tentang kesetaraan gender, khususnya masyarakat yang berpendidikan tinggi. Istri tidak lagi hanya berkutat dengan urusan "kasur", "sumur", dan "dapur" saja, kini mereka telah mampu berperan di ranah publik, ranah yang dulunya hanya untuk suami atau laki-laki saja, bahkan terkadang istri yang memegang penuh peran publik menjadi tulang punggung keluarga mencari nafkah menggantikan suaminya, terkadang pula istri mempunyai peran ganda, berperan publik sekaligus domestik.

Berkaitan dengan peran suami dan istri dalam keluarga, Partini berpendapat bahwa pekerjaan publik maupun domestik pada dasarnya dapat dipertukarkan satu dengan lainya, sehingga perbedaan peran tersebut tidak perlu bersifat kaku, kecuali untuk peran yang berkaitan dengan faktor biologis, yang menjadi kodrat, atau yang merupakan bawaan sejak lahir. ${ }^{29}$

Pasangan suami istri yang samasama bekerja membutuhkan keterbukaan dalam melakukan pertukaran peran dan berbagi tugas untuk menyelesaikan pekerjaan rumah tangga (peran domestik) maupu untuk mencari nafkah (peran

${ }^{29}$ Partini, Bias Gender dalam Birokrasi, (Yogyakarta: Tiara Wacana, 2013), hlm. 29. 
publik). ${ }^{30}$ Dalam hal ini, prinsip mu'asyaroh bi al-ma'ruf sebagaimana yang dicontohkan oleh Rasul dapat digunakan sebagai kunci bagaimana pembagian tugas domestik antara suami dan istri, pembagian tugas ini dapat dilakukan dengan musyawarah sehingga masing-masing tidak merasa terbebani karna berperan ganda. Kemudian perwujudan kerjasamanya dapat didasarkan pada prinsip kesetaraan dan keseimbangan dalam keluarga.

Pasangan suami-istri yang notabene mempunyai latar belakang pendidikan tinggi cenderung kepada pola hubungan modern di mana pembagian peran dalam keluarga bersifat luwes atau tidak kaku, sehingga antara suami-istri tidak merasa terbebani jika melakukan peran publik dan domestik secara bergantian ataupun bersama-sama karena telah kesepakatan sebagai buah dari komunikasi yang berjalan baik dalam keluarga. Namun yang menjadi masalah adalah ketika salah satu atau keduanya tidak mampu membagi peran tersebut dengan baik sehingga memberatkan salah satu pihak. Sebagaimana hasil penelitian yang dilakukan oleh Nurhikmah Hairak H. Biga, bahwa kebanyakan pasangan bercerai dengan latar belakang pendidikan yang tinggi adalah karena ketidakseimbangan peran antara suami-istri. Hal ini disebabkan oleh kelalaian suami dalam menafkahi, istri yang lalai mengatur pengeluaran keluarga, otoritas suami yang lebih besar dalam keluarga sehingga istri merasa berada pada kedudukan yang subordinatif, istri menduduki posisi double burden di mana suami tidak menafkahi keluarga dan istri sebagai pemberi nafkah sekaligus menjalankan peranya sebagai pengurus rumah tangga tanpa bantuan suami. $^{31}$

30 Iftidah, "Pengaruh Pemahaman Keagamaan Masyarakat Desa Dempet Terhadap Pola Relasi Suami Isteri Bekerja”, hlm, 522.

${ }^{31}$ Nurhikmah Hairak H. Biga, "Pembagian Peran dalam Keluarga dan Pengaruhnya Terhadap
Dari keterangan di atas, dapat kita ketahui begitu besar dampak peralihan peran suami-istri dalam sebuah keluarga, khususnya pada keluarga dengan latar belakang suami-istri berpendidikan tinggi, untuk itu dalam membangun relasi keluarga, pembagian tugas, dan pertukaran peran menjadi sangat penting dilakukan dengan sebaik mungkin dengan berprinsip mu'asyaroh bi al-ma'ruf, kesetaran dan keseimbangan dalam keluarga untuk mewujudkan keluarga yang harmonis, keluarga yang sakinah, mawaddah, warohmah.

\section{Kesimpulan}

Dari pembahasan di atas, penulis menyimpulkan bahwa, dalam sebuah keluarga, setiap anggota keluarga mempunyai fungsi atau peranya masingmasing. Pasangan suami-istri yang notabene mempunyai latar belakang pendidikan tinggi cenderung kepada pola hubungan modern di mana pembagian peran dalam keluarga bersifat luwes atau tidak kaku, sehingga antara suami-istri tidak merasa terbebani jika melakukan peran publik dan domestik secara bergantian ataupun bersama-sama karena telah kesepakatan sebagai buah dari komunikasi yang berjalan baik dalam keluarga. Namun yang menjadi masalah adalah ketika salah satu atau keduanya tidak mampu membagi peran tersebut dengan baik sehingga memberatkan salah satu pihak. Begitu besar dampak peralihan peran suami-istri dalam sebuah keluarga, khususnya pada keluarga dengan latar belakang suami-istri berpendidikan tinggi, untuk itu dalam membangun relasi keluarga, pembagian tugas, dan pertukaran peran menjadi sangat penting dilakukan dengan sebaik mungkin dengan berprinsip mu'asyaroh bi al-ma'ruf, kesetaran dan keseimbangan dalam keluarga untuk mewujudkan keluarga yang harmonis, keluarga yang sakinah, mawaddah, warohmah.

Perceraian Pasangan Muslim Berpendidikan Tinggi", hlm. 129. 


\section{Daftar Pustaka}

Aziz, Hannan Abdul, Saat Istri Punya Penghasilan Sendiri, Solo: PT. Aqwam Media Profetika, 2012.

Biga, Nurhikmah Hairak H., "Pembagian Peran dalam Keluarga dan Pengaruhnya Terhadap Perceraian Pasangan Muslim Berpendidikan Tinggi" Tesis, Fakultas Syari'ah dan Hukum Universitas Islam Negeri Sunan Kalijaga Yogyakarta, 2015.

Ch, Mufidah, Psikologi Keluarga Islam Berwawasan Gender (Edisi Revisi), Malang: UIN-Maliki Press, 2014.

Ghozali, Abdul Rahman, Fiqh Munakahat, Jakarta : Kencana, 2003.

Hamzani, Achmad Irwan, "Pembagian Peran Suami Istri dalam Keluarga Islam Indonesia (Analisis Gender terhadap Inpres No. 1 tahun 1991 tentang Kompilasi Hukum Islam)", Jurnal SOSEKHUM (eJournal.uptegal.ac.id), 2010.

Hendrati, Maria Agustin dan Fabiola, "Hubungan Kemandirian Istri dengan Keharmonisan Perkawinan pada Tahap Awal Perkawinan di Kelurahan Pagentan Kecamatan Singosari Kabupaten Malang", Jurnal Psikologi Tabularasa, Volume, No. 2, Agustus 2013.

Iftidah, "Pengaruh Pemahaman Keagamaan Masyarakat Desa Dempet Terhadap Pola Relasi Suami Istri Bekerja", Jurnal HARMONI: Multikultural dan Multireligius Vol. 17, No. 2, JuliDesember 2018.

Ismiyati, "Tinjauan Yuridis Tentang Relasi Suami-Istri Menurut KHI Inpres No. 1/1991", Jurnal MMH Fakultas Hukum Universitas Diponegoro Semarang, Jilid 42, No. 3, Juli 2013.

Nasution, Khoiruddin, Hukum Perdata (Keluarga) Islam Indonesia dan Perbandingan Hukum Perkawinan di Dunia Muslim, Yogyakarta: ACAdeMIA + TAZZAFA, 2009.

Partini, Bias Gender dalam Birokrasi, Yogyakarta: Tiara Wacana, 2013.

Puspitawati, Herien, "Konsep dan Teori Keluarga”, Departemen Ilmu Keguruan dan Konsumen Fakultas Ekologi Manusia-IPB, 2013.

Sabiq, Sayyid, Fiqh Sunnah, II, Jakarta: Darul Haq, tt.

Sapitri, Elvida, "Pembagian Peran Antara Suami Istri Dan Implikasinya Terhadap Keharmonisan Keluarga (Studi Kasus di Gampong Lawe Cimanok Kecamatan Kluet Timur Kabupaten Aceh Selatan)" Skripsi, Fakultas Dakwah dan Komunikasi Jurusan Pengembangan Masyarakat Islam Universitas Islam Negeri ArRaniry, 2017.

Soekanto, Soerjono, Budi Sulistiyowati, Sosiologi Suatu Pengantar, Jakarta : Rajawali Press, 2017.

Syarifuddin, Amir, Hukum Perkawinan Islam di Indonesia (Analisis Fiqh Munakahat dan Undang-Undang Perkawinan), Jakarta: Kencana, 2006.

Tim Penterjemah Alquran Kemenag RI, Alquran dan Terjemahnya, Surakarta: Pustaka Al Hanan, 2009. 